\title{
ROSSETTI, Livio. $O$ diálogo socrático. Tradução de Janaína Mafra. São Paulo: Editora Paulus, 2015. (Col. Cátedra). 312 p.
}

\section{Janaína Mafra}

Universidade Federal de Minas Gerais (UFMG), Belo Horizonte, Minas Gerais /Brasil janasilmafra@gmail.com

https://orcid.org/0000-0002-6413-0280

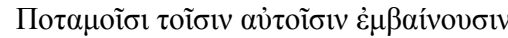

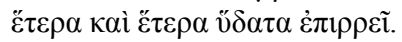

Ao entrarem nos mesmos rios, outras e outras águas fluem por cima. ${ }^{1}$

(Heráclito de Éfeso DK 22 B 12 = Ário Dídimo em Eusébio, P. E., XV, 20)

Publicados inicialmente como capítulos de livros e artigos isolados, os oito textos reunidos em $O$ diálogo socrático são uma amostra do fluxo da produção de Livio Rossetti acerca do tema, fluxo sob o qual se preserva uma unidade estrutural estimulantemente aberta.

Em "O diálogo socrático in statu nascendi", é avaliado o alcance de um fenômeno cultural que acontece na primeira metade do século IV a.C.: a produção de centenas de lógoi sokratikói. Esse fenômeno é subavaliado pela comunidade científica que, por um hábito pouco questionado, concentra-se em Platão, negligenciando uma lista de outros socráticos. Questionando esse hábito, L. Rossetti chama a atenção do leitor para o salto de tal produção em relação aos discursos da época, salto impulsionado pelas habilidades literárias dos socráticos que, empenhados

${ }^{1}$ A tradução do grego é de nossa responsabilidade. 
em garantir ao gênero um alto nível de inventividade, o renovaram e o imortalizaram.

Em "O Eutidemo de Xenofonte", é explicitado o projeto macrorretórico da seção IV 2 dos Memoráveis. Após montar uma armadilha para Eutidemo, Sócrates lhe dirige uma rajada de contraexemplos e o constrange a abandonar seus enunciados de caráter geral. Diante desse cenário, L. Rossetti evoca a conhecida imagem dos rios de Heráclito e, com ela, a noção de verdade complementar (e, portanto, não exclusiva!), interpretada como a porção da verdade que começa onde termina o domínio de aplicação de uma afirmação de caráter geral. Ele nos mostra que o Sócrates de Xenofonte se vale de artifícios para pôr Eutidemo em dificuldade, mas que sua conduta é instrumental, já que sua finalidade é provocar uma reflexão no interlocutor.

Em "Saber imitar é conhecer: o caso de Memoráveis III 8", L. Rossetti prova que Xenofonte é uma fonte importante do modo socrático de praticar a refutação. Após recuperar o papel de questionador que Sócrates havia lhe tomado, Aristipo vale-se aí de uma ferramenta dialética familiar aos socráticos: ele tenta levar Sócrates (seu professor na matéria) a universalizar a fim de lhe dirigir uma rajada de contraexemplos. Ao darse conta de que Sócrates insiste na diversidade e evita a universalização, Aristipo insinua, em vão, que ele não se atém às "regras" da conversa, "regras" tipificadas pelos socráticos e reconhecidas não só por Aristipo, mas também por Xenofonte, que as tematiza, atestando a existência de uma rede conceitual amplamente partilhada pelos alunos do filósofo.

Em “O Êtifron como acontecimento comunicativo", L. Rossetti ressalta uma componente estrutural dos diálogos aporéticos de Platão (dos quais o Êtifron é parte): o movimento incessante que eles engendram naqueles que desejam levar a pesquisa "definicional" adiante. Esse movimento resulta em um percurso hiperbólico capaz de implicá-los na busca de uma definição que se torna insuficiente a cada vez, ainda que avanços tenham sido conquistados. Esse resultado mobiliza energias importantes que, após terem sido estrategicamente freadas, podem se desenvolver de modo mais livre, inclusive em relação a Platão, ao menos 
se o leitor se torna filósofo e, com um pouco mais de autonomia, tenta ir mais longe.

Em "O ridículo como arma nas mãos de Sócrates e de seus alunos”, L. Rossetti trata não só do aspecto involuntário do ridículo (qualquer um, por descuido ou por engano, pode ser vítima dele), mas também do seu potencial agonístico. Esse último serve tanto à tékhne lógon socrática quanto à dos sofistas, já que ambas se valem da contradição para tornar irrisórias as posições dos antagonistas. A primeira dessas tékhnai, entretanto, mais do que pretender persuadir os ouvintes da justeza de uma opinião, pretende provocar no interlocutor uma crise salutar capaz de abrir o seu espírito. É ao tecido multicolorido de seus aspectos (cômicos e sérios) que o ridículo socrático deve a sua força, a ponto de, com ou sem razão, ter desacreditado os sofistas durante muito tempo aos olhos do ocidente.

Em "A retórica de Sócrates", L. Rossetti trata tanto da dificuldade de se resistir aos efeitos da "retórica da antirretórica" quanto da urgência de se considerar as estratégias comunicativas de Sócrates (a afetação de espontaneidade, de ingenuidade e de amnésia, a ironia, a refutação, as analogias e os contraexemplos...) como aspectos constitutivos de uma arte retórica inédita. Após traçar os pontos convergentes e divergentes entre a retórica socrática e a gorniânica, o autor persuade até mesmo o leitor renitente de que, na medida em que a (macro)retórica socrática fala mais de fins do que de meios, ela fala daquilo que Sócrates deseja instilar no espírito de seus interlocutores, o que a torna uma via de acesso privilegiada ao universo mental do filósofo ou, dito de outro modo, às diferentes facetas de sua figura histórica.

Em "O lado inautêntico do dialogar platônico" são avaliadas duas perspectivas exegéticas dos diálogos de Platão: a da escola de Tübingen-Milão, que pressupõe a necessidade de Platão socorrer (boethein) o leitor na decodificação das doutrinas, e a dos analíticos, que pretendem isolar os argumentos sem se interrogarem sobre o que tiveram que deixar de lado para isolá-los. Sem se identificar com nenhuma dessas ortodoxias exegéticas, mas sem deixar de aproveitar seus pontos positivos, L. Rossetti propõe uma interpretação flexível dos diálogos. Ele 
favorece, assim, a pesquisa sobre a relação entre os pontos de doutrina e seu envolvimento em um fluxo comunicativo sutil e insidioso: para alcançar os pontos de doutrina, e ele adverte o leitor da dificuldade da tarefa, é preciso considerar tudo o que eles não são e também a função desempenhada pelos elementos de seu envolvimento, o que demanda a destilação de uma mistura que, por sua vez, é extraordinariamente refratária a tal procedimento.

Em “Os socráticos 'primeiros filósofos' e Sócrates 'primeiro filósofo", L. Rossetti aborda um tema que geralmente gera desdobradas controvérsias. Uma vez que Sócrates e os socráticos utilizaram os termos "filosofia" e "filósofo" para designar uma atividade inédita de pensamento e fazer referências objetivadas a si próprios, eles devem ser considerados como os primeiros "filósofos". O que implica um questionamento da "história" da filosofia inaugurada por Aristóteles, que atribuiu o título de "filósofos" aos autores das obras intituladas Perì phúseos e a outros intelectuais, como Tales e Demócrito, estabelecendo, assim, uma convenção mais do que razoável que acabou criando raízes.

Uma vez que comportam uma renovação considerável da percepção do conjunto dos lógoi sokratikói, assim como da personalidade de Sócrates, os oito textos reunidos em $O$ diálogo socrático são, por eles mesmos, um convite à sua leitura.

Agradecemos ao Prof. Livio Rossetti (Universidade de Perugia), por nos ter confiado a tradução de seu livro (ROSSETTI, Livio. Le dialogue socratique. Coll. "Encre Marine”. Paris: Les Belles Lettres, 2011), acrescentando um Prefácio e um Posfácio originais à edição brasileira.

Recebido em: 26 de novembro de 2020.

Aprovado em: 4 de dezembro de 2020. 